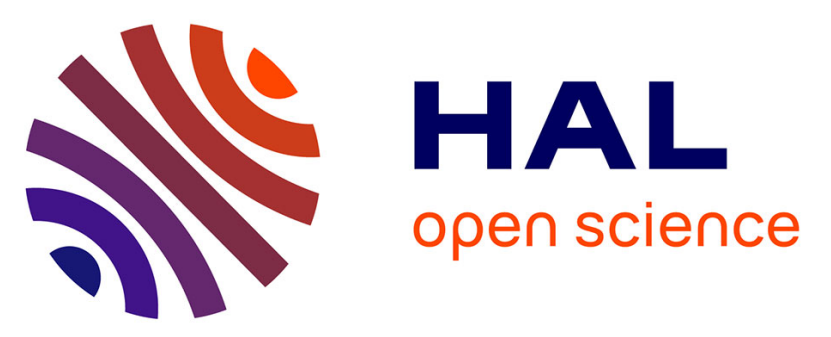

\title{
Soil carbon stocks under different land uses and the applicability of the soil carbon saturation concept
}

Songchao Chen, Dominique Arrouays, Denis Angers, Manuel P. Martin, Christian Walter

\section{- To cite this version:}

Songchao Chen, Dominique Arrouays, Denis Angers, Manuel P. Martin, Christian Walter. Soil carbon stocks under different land uses and the applicability of the soil carbon saturation concept. Soil and Tillage Research, 2019, 188, pp.53-58. 10.1016/j.still.2018.11.001 . hal-02074739

\section{HAL Id: hal-02074739 \\ https://hal.science/hal-02074739}

Submitted on 21 Oct 2021

HAL is a multi-disciplinary open access archive for the deposit and dissemination of scientific research documents, whether they are published or not. The documents may come from teaching and research institutions in France or abroad, or from public or private research centers.
L'archive ouverte pluridisciplinaire HAL, est destinée au dépôt et à la diffusion de documents scientifiques de niveau recherche, publiés ou non, émanant des établissements d'enseignement et de recherche français ou étrangers, des laboratoires publics ou privés.

\section{(ㄷ)(1) $\$$}

Distributed under a Creative Commons Attribution - NonCommercial| 4.0 International 
1 Title: Soil carbon stocks under different land uses and the applicability of the soil

2 carbon saturation concept

3

4 Authors:

5 Songchao Chen a, b. songchao.chen@inra.fr

6 Dominique Arrouays ${ }^{a}$. dominique.arrouays@inra.fr

7 Denis A. Angers ${ }^{\text {c. denis.angers@agr.gc.ca }}$

$8 \quad$ Manuel P. Martin a. manuel.martin@inra.fr

$9 \quad$ Christian Walter b. christian.walter@agrocampus-ouest.fr

\section{Affiliations:}

a INRA, Unité InfoSol, 45075, Orléans, France

b UMR SAS, INRA, Agrocampus Ouest, 35042 Rennes, France

${ }^{c}$ Quebec Research and Development Centre. Agriculture and Agri-Food Canada,

Québec, GIV 2J3 Canada

Corresponding author:

Dominique Arrouays: dominique.arrouays@inra.fr

Postal address: INRA, Unité InfoSol, 2163 Avenue de la Pomme de Pin, CS 40001

Ardon, 45075 Orléans, France 


\section{Abstract}

Increasing soil organic carbon (SOC) stocks via land management has been proposed as a temporary climate change mitigation measure. An upper limit of soil stable SOC storage, which refers to the concepts of SOC saturation has been proposed. Using systematic grid sampling of topsoil in mainland France and an equation that predicts this SOC saturation, we derived estimates of the SOC sequestration potential density $\left(\mathrm{SOC}_{\mathrm{spd}}\right)$ for various land uses. First, using French database and data from the literature we estimated the proportions of the SOC stored in the fine fraction (SOC fine $_{\text {) }}$ in total SOC for grassland $(69 \%)$, cropland $(85 \%)$ and forest $(66 \%)$. Then, $\mathrm{SOC}_{\text {spd }}$ was calculated as the difference between the theoretical SOC saturation value and $\mathrm{SOC}_{\text {fine. }}$ The $\mathrm{SOC}_{\text {spd }}$ Stocks for French topsoil were estimated at about $1.1 \mathrm{Pg}$, in which cropland, forest and grassland accounted for $66 \%, 17 \%$ and $17 \%$, respectively. Varying the proportions of $\mathrm{SOC}_{\text {fine }}$ in the calculations by assuming a possible range of 0.8-0.9 for cropland and 0.6-0.9 for grassland and forest soils led to variations of total $\mathrm{SOC}_{\text {spd }}$ stocks of about $0.1 \mathrm{Pg}$ for each land use. Most importantly, we demonstrate that the distribution of $\mathrm{SOC}_{\text {spd }}$ in forest soils is exactly centred at zero, which suggests that on average, forest topsoils are saturated in $\mathrm{SOC}_{\text {fine, }}$ and thus Hassink's equation provides a valid estimate for the SOC sequestration potential for French topsoil.

\section{Keywords}

Soil organic carbon; Soil carbon saturation; Carbon sequestration potential; Land use; Forest soils 


\section{Introduction}

Soil organic carbon (SOC) plays a major role in the global greenhouse gas balance (Lal, 2004, 2010). Soils throughout the world store four times more SOC than the biosphere and approximately two to three times more carbon than the atmosphere (Batjes, 1996; Stockmann et al., 2015; Le Quéré et al., 2016). Thus, a relatively small change in this reservoir may have a large effect on $\mathrm{CO}_{2}$ balance. Anthropogenic perturbations have strongly depleted SOC stocks (Bellamy et al., 2005; Sanderman et al., 2017) contributing significantly to increased $\mathrm{CO}_{2}$ concentration (Canadell et al., 2007). Increasing SOC is beneficial not only for mitigating climate change but also for restoring degraded soils with major potential impacts on crop yields, food security, and the well-being of smallholder farmers (Smith et al., 2008, 2012; Chabbi et al., 2017; Paustian et al., 2016). At the $21^{\text {st }}$ session of the United Nations Framework Convention on Climate Change (UNFCCC, COP21), a voluntary action plan, the " 4 per 1000 Initiative: Soils for Food Security and Climate" was proposed (https://www.4p1000.org/). The 4 per 1000 initiative is intended to foster food security and reduce atmospheric $\mathrm{CO}_{2}$ concentration by increasing the $\mathrm{SOC}$ stocks at an annual rate of $0.4 \%$.

Interest around the feasibility, range and duration of additional SOC sequestration has rapidly risen (Lu et al., 2011; Smith et al., 2012; Bradford et al., 2016; Paustian et al., 2016; Chabbi et al., 2017; Dignac et al., 2017; Minasny et al., 2017; van Groenigen et al., 2017). But it has also generated controversy, such as the need for additional nitrogen input to meet stoichiometric demand, the feasibility of implementing changes in management, and the non-permanence of the SOC stocks (Smith, 2005; van Groenigen et al., 2017; Poulton et al., 2018). However, there is a general consensus regarding beneficial practices that may increase SOC (Smith et 
al., 2008; Lal, 2010; Smith et al., 2012; Paustian et al., 2016; Chabbi et al., 2017; Dignac et al., 2017; Minasny et al., 2017; Chenu et al., 2018).

Bonding of SOC to the fine mineral particles is considered one of the most significant SOC stabilization mechanisms for mineral soils (Hassink, 1997; Baldock and Skjemstad, 2000; Six et al., 2002), and as the amount of fine particles is finite, the hypothesis of an upper limit of soil stable SOC storage, which refers to SOC saturation, is generally accepted (Hassink, 1997; Baldock and Skjemstad, 2000; Six et al., 2002; Stewart et al., 2007; Dignac et al., 2017). Hassink (1997) proposed an equation to describe the relationship between maximum SOC storage in the fine fraction, which is assumed to be more stable than the coarse SOC, and the soil fine fraction $(<20 \mu \mathrm{m}$, clay and fine silt) for world soils. In this context, the fine fraction represents a proxy for the mineral surface. The SOC saturation deficit or SOC sequestration potential $\left(\mathrm{SOC}_{\mathrm{sp}}\right)$ can be calculated as the difference between the theoretical SOC saturation and the SOC stored in the fine fraction (SOCfine).

Here, we make a distinction between SOC sequestration, defined as long-term stabilized SOC associated with the soil fine fraction, and soil SOC storage, which refers to the whole-soil SOC content (including the coarse or sand-size fraction) (Chenu et al., 2018). Recent discussions have emphasized that the saturation deficit concept may not be suitable to estimate short- to medium-term (10-30 years) wholesoil (including the sand-size fraction) SOC storage potential under varying agro- and climatic conditions (Barré et al., 2017). Indeed, the SOC saturation concept only applies to the soil fine fraction and is theoretically related to the inherent capacity of soils to stabilize (sequester) SOC in the long term in the fine fraction (Hassink, 1997). Other tools (e.g., data-driven approaches and process-based prediction models) may 
be more appropriate to estimate the whole-soil SOC storage potential under varying management and climatic conditions for a given period of time (Barré et al., 2017).

Changes in land cover and land use have a major effect on SOC stocks (Post and Kwon, 2000; Guo and Gifford, 2002; Lal, 2010; Smith et al., 2012; Stockmann et al., 2015). Forests and grasslands usually show the highest SOC stocks among land covers (Carter et al., 1998; Post and Kwon, 2000; Conant et al., 2001; Guo and Gifford, 2002; Soussana et al., 2004; McNally et al., 2017). Forest and grassland soils are therefore often used as reference for the maximum reachable SOC stocks and SOC saturation (Conant et al., 2001; Guo and Gifford, 2002; Lugato et al., 2014).

Here we analyse the statistical distribution of SOC sequestration potential density (SOC $\mathrm{spd}$ ) from an unbiased sampling of topsoil in mainland France. Our objectives were to apply the carbon saturation concept for French topsoil, to estimate their $\mathrm{SOC}_{\mathrm{spd}}$, and to determine if some land uses could be used as a reference for estimating soil SOC sequestration potential.

\section{Material and methods}

\subsection{Sampling and measurements}

Data come from the systematic grid of the French Soil Monitoring Network (RMQS). This network is based on a $16 \mathrm{~km} \times 16 \mathrm{~km}$ square grid and the sites are selected at the center of each grid cell resulting in about 2000 soil sampling sites (Martin et al., 2011). Twenty-five individual core samples were collected for topsoil $(0-30 \mathrm{~cm})$ based on an unaligned sampling design within a $20 \mathrm{~m} \times 20 \mathrm{~m}$ square, and then were mixed into a composite sample for each site. In the south border of the $20 \mathrm{~m} \times 20 \mathrm{~m}$ square, a soil pit was dug to record main soil characteristics including bulk density with three replicates. Soil organic carbon content was measured using an automated C-N 

137 fraction $\left(\mathrm{g} \mathrm{kg}^{-1}\right)$. follows:

analyzer by the dry combustion method (Thermofisher NA 2000) and bulk density was determined by taking samples of known volume and drying them to constant weight. Particle-size analysis was determined using the pipette method. More details about the sampling strategy are found in Chen et al. (2018).

\subsection{Calculation of SOC sequestration potential}

The SOC saturation of soil fine fraction $(<20 \mu \mathrm{m}$, clay and fine silt) was calculated according to the equation proposed by Hassink (1997):

$$
S O C_{\text {sat }}=4.09+0.37 \times \text { fine fraction }
$$

where $S O C_{\text {sat }}$ is the $\mathrm{SOC}$ saturation $\left(\mathrm{g} \mathrm{kg}^{-1}\right)$ and fine fraction is the content of soil particle-size $<20 \mu \mathrm{m}(\%)$.

The SOC saturation deficit was calculated as the difference between SOC saturation and the SOC stored in soil fine fraction $\left(\mathrm{SOC}_{\text {fine }}\right)$. The $\mathrm{SOC}_{\text {fine }}$ content of cropland soils was assumed to comprise $85 \%$ of the total SOC based on previous studies (Balesdent, 1996; Jolivet et al., 2003; Angers et al., 2011). We also summarized previous studies from regions with similar climate (Table 1) and derived the proportions of $\mathrm{SOC}_{\text {fine }}$ in the total $\mathrm{SOC}$ by weighted averaging (according to the number of samples per study) for grassland $(69 \pm 9 \%)$ and forest $(66 \pm 2 \%)$.

The $\mathrm{SOC}$ saturation deficit or $\mathrm{SOC}$ sequestration potential $\left(\mathrm{SOC}_{\mathrm{sp}}\right)$ was calculated as

$$
S O C_{s p}=S O C_{s a t}-S O C_{\text {fine }}
$$

where $S O C_{s p}$ is the $S O C$ sequestration potential $\left(\mathrm{g} \mathrm{kg}^{-1}\right)$ and $S O C_{\text {fine }}$ is $\mathrm{SOC}$ in fine

138 The SOC sequestration potential density was calculated using the following equation: 


$$
\mathrm{SOC}_{\mathrm{spd}}=p \times S O C_{s p} \times B D \times(100-c e) \times 10^{-2}
$$

where $S O C_{s p d}$ is the $\mathrm{SOC}$ sequestration potential density $\left(\mathrm{kg} \mathrm{m}^{-2}\right)$ in topsoil layer (0$30 \mathrm{~cm}), B D, S O C_{s p}$ and ceare the bulk density $\left(\mathrm{kg} \mathrm{m}^{-3}\right)$, sequestration potential $\left(\mathrm{g} \mathrm{kg}^{-}\right.$

$142{ }^{1}$ or $\%$ ), ce is thepercentage of coarse elements ( $\left.>2 \mathrm{~mm}, \%\right)$, and $p$ is the thickness $143(\mathrm{~m})$ of topsoil horizon.

144 As the RMQS is a systematic grid covering the whole territory (mainland France), it can be used in a straightforward and unbiased way to estimate mean values and total SOC $_{\text {spd }}$ stocks (Brus and de Gruijter, 1997). Using RMQS sites we calculated the estimates of $\mathrm{SOC}_{\text {spd }}$ Stocks at the national scale. Estimates of $\mathrm{SOC}_{\text {spd }}$ Stocks were calculated by multiplying the total area of each land use by its mean $\mathrm{SOC}_{\text {spd }}$ (negative values were replaced by 0 as they have by definition no potential to sequester SOC) of observed RMQS sites under cropland, forest and grassland.

\subsection{Sensitivity analysis}

As a large part of uncertainty comes from the parameter setting for the proportion of $\mathrm{SOC}_{\text {fine }}$ in the total SOC for each land use, we first assessed the influence of proportion setting on the estimates of French national $\mathrm{SOC}_{\text {spd }}$ Stocks in topsoil.

\section{Results}

3.1. SOC sequestration potential under land uses 
The relative frequency distribution of $\mathrm{SOC}_{\mathrm{spd}}$ was analysed for three main land uses: forest, grassland and cropland (Fig. 1). Positive values indicate the potential to sequester additional stable SOC, whereas negative values indicate seemingly oversaturated soils, the implication of which is discussed later. Nearly $84 \%$ of cropland soils are depleted in stable SOC, with a modal $\mathrm{SOC}_{\mathrm{spd}}$ value of approximately $4 \mathrm{~kg} \mathrm{~m}^{-2}\left(40 \mathrm{Tg} \mathrm{ha}^{-1}\right)$.

The relative frequency distribution of $\mathrm{SOC}_{\text {spd }}$ of forest soils is exactly centred at zero. Its mean, modal and median values are $0.06,0$, and $0.28 \mathrm{~kg} \mathrm{~m}^{-2}$, respectively. The distribution is skewed and exhibits a tail for most negative values, which suggests that some forest soils may be oversaturated in stable SOC.

Skewness is also observed for the relative frequency distribution of $\mathrm{SOC}_{\text {spd }}$ under grassland. The distribution is centered at $2 \mathrm{~kg} \mathrm{~m}^{-2}$ with a sharp increase in the frequency around this value, whereas its median value is close to zero $\left(-1.40 \mathrm{~kg} \mathrm{~m}^{-2}\right)$. Among the three frequency distributions, the values under forest are the most scattered and show a large proportion of negative values.

\subsection{SOC sequestration potential density and soil fine fractions}

The $\mathrm{SOC}_{\text {spd }}$ is related to the fine mineral particle fraction $(0-20 \mu \mathrm{m})$ as per Hassink's equation. There is a general increase in $\mathrm{SOC}_{\text {spd }}$ with an increase in fine fraction content, but the magnitude differs between land uses (Fig. 2). Cropland soils show a greater slope value (0.08) and Pearson correlation coefficient (0.47) of the fitted line between $\mathrm{SOC}_{\text {spd }}$ and fine fraction content than forest and grassland soils. This result suggests that the increase in $\mathrm{SOC}_{\mathrm{spd}}$ with increasing fine fraction is highest for cropland.

3.3. $\quad$ SOC $_{\mathrm{spd}}$ stocks and sensitivity analysis 
The SOC spd stocks in French topsoil were about $1.1 \mathrm{Pg}$, of which cropland, forest and grassland accounted for $66 \%, 17 \%$ and $17 \%$, respectively. Varying the proportion of SOCfine in the calculation (assuming a possible range of 0.8-0.9 for croplands and

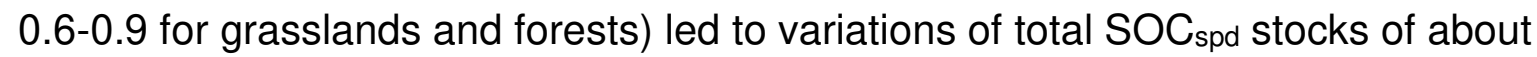
$0.1 \mathrm{Pg}$ for each land use (Fig. 3). Fig. 4 shows that the $\mathrm{SOC}_{\text {spd }}$ distribution is very sensitive to variation in the proportion of $\mathrm{SOC}_{\text {fine }}$ used. The flatter and the wider is the distribution of $\mathrm{SOC}_{\text {fine, }}$, the larger is the range of $\mathrm{SOC}_{\text {spd }}$ for simulated forest soils that had a $\mathrm{SOC}_{\text {spd }}$ close to zero when using the fixed value of 0.66 for the $\mathrm{SOC}_{\text {fine }}$ proportion.

\section{Discussion}

The observed differences among land uses in topsoil confirm the well-known effect of SOC depletion with cultivation (Post and Kwon, 2000; Conant et al., 2001; Guo and Gifford, 2002; McNally et al., 2017). The mean values that we obtained for cropland, grassland and forest soils are consistent with trends of SOC associated with land use change reported in the literature (Post and Kwon, 2000; Guo and Gifford, 2002). Among the invoked limitations of the SOC saturation concept, is the lack of field validation (O'Rourke et al., 2015). Our findings indicate that the SOC saturation concept for the French climate is sensitive to land use. Similar ranges of $\mathrm{SOC}_{\text {spd }}$ have been identified for cultivated soils using an entirely different and independent data set (Angers et al., 2011) which indicates that our findings are robust.

Following a previous study (Angers et al., 2011), we postulated that part (15\%) of the SOC measured in cropland soil was not bound to minerals and was unprotected. Similarly, we used lower values from the literature to estimate this proportion of unprotected SOC in grassland and forest soils as a higher proportion of unbound 
211 SOC is usually observed in these soils. Although we adapted the proportion to land use, we may have under- or overestimated the protected SOC in some soils with very high SOC contents. Moreover, our sensitivity analysis shows that SOCspd is very sensitive to the proportion of $\mathrm{SOC}_{\text {fine }}$ used in the calculations. Assuming that there is a variation around the mean values we used, a large part of the dispersion in $\mathrm{SOC}_{\mathrm{spd}}$ under forest soils may be attributable to the variability in the proportion of $\mathrm{SOC}_{\text {fine. }}$. This may also explain why we find some negative values of $\mathrm{SOC}_{\text {spd }}$ (oversaturation of the fine fraction) which should not happen in theory.

To estimate stable SOC saturation, we employed an equation that was derived for soils from around the world (Hassink, 1997). Therefore, some bias and uncertainty may be associated with the derived estimates. The equation we used is linear; however, as suggested by some authors (Stockmann et al., 2013), this relation may follow a curve that reaches a plateau at high fine particle content.

Unlike many previous studies looking at national/regional estimates of SOC sequestration, our results are statistically unbiased. Indeed, our sampling scheme, which is based on a systematic grid for which the origin was not purposely chosen, corresponds to the standards of an unbiased statistical sample. Apart from noticeable exceptions (e.g., Bellamy et al., 2005, Wiesmeier et al., 2014), most of the broadscale inventory or monitoring schemes are based on purposive sampling that is useful for understanding causes of variation but may be biased when applying statistics to determine a mean value or a total stock at a national scale.

One striking finding is that $\mathrm{SOC}_{\text {spd }}$ under forest exhibits a peak relative frequency distribution that is exactly centred at zero. The fact that the potential additional sequestration is centered at zero under forest suggests that "on average" their fine 
235 fraction is saturated. This does not mean that, for a specific pedo-climate context, forest soils are saturated. However, French forest soils, considered as a whole, provide an adequate reference to estimate the maximum sequestration potential overall, for the French territory. The higher mean $\mathrm{SOC}_{\text {spd }}$ in grassland may result from the fact that some grassland soils have been already degraded probably due to SOC export from intensive grazing. This may also be related to the fact that grassland soils are on average more clayey ( $25 \%$ clay or $48 \%$ fine fraction) than forest soils ( $22 \%$ clay or $43 \%$ fine fraction), and, as we can see in Fig. 2 , the SOC $_{\text {spd }}$ tends to increase with fine fraction content.

The SOC $_{\text {spd }}$ Stocks for French topsoil under the three main land uses was estimated to be about $1.1 \mathrm{Pg}$. This potential additional SOC sequestration can be compared to recent estimates of total SOC stocks in French topsoil of about 3.5 Pg (Martin et al., 2011; Meersmans et al., 2012; Mulder et al, 2016). This potential additional amount of SOC stocks represents $4.0 \mathrm{Pg} \mathrm{CO}_{2}$ equivalent, that is about 12.6 times the French annual $\mathrm{CO}_{2}$ emission in $2013(0.32 \mathrm{Pg})$ (Eurostat, 2015). Cropland has the highest potential to sequester with nearly $66 \%$ of the total. The fact that our calculations show that a large additional sequestration potential exists in theory does not necessarily mean that it can be reached in practice. Innovative management practices (Chenu et al., 2018) will need to be developed and proposed to take advantage of this high sequestration potential. Many factors may limit both the duration and potential of SOC sequestration. Among those factors limiting SOC sequestration potential are for instance $\mathrm{N}$ and $\mathrm{P}$ availability and climatic or water regime effects on net primary productivity and SOC mineralization and stabilization (van Groenigen et al., 2017). It may be that under French climate, the conditions for an optimal SOC sequestration cannot be reached. Moreover, some options for a 
maximal SOC sequestration are clearly not realistic (e.g., converting all croplands to grassland or forest) or may not be feasible according to technical, economic or social constraints.

Finally, there is a need to refine our estimate of SOC in the fine fractions for French soils in order to derive more reliable estimates of $\mathrm{SOC}_{\text {spd. }}$. Further, other approaches to estimate the potential for additional SOC storage, such as data-driven or mechanistic C models (Barré et al., 2017), need to be developed in order to improve the national estimates, their driving factors, and identify suitable land management practices.

\section{Conclusion}

We estimated $\mathrm{SOC}_{\text {spd }}$ using an unbiased sampling of topsoil in mainland France and estimates of the proportion of $\mathrm{SOC}_{\text {fine }}$ compiled from the literature. Our results showed that French topsoils have a large potential to sequester SOC (1.1 Pg) when compared to the total SOC stocks (3.5 Pg). A sensitivity analysis suggested that actual measurements of the proportion of SOCfine would be helpful to decrease the uncertainty of $\mathrm{SOC}_{\text {spd }}$ estimates. As the distribution of $\mathrm{SOC}_{\text {spd }}$ in forest soils is centred at zero, we suggest that it may be used as a reference to estimate the maximum SOC sequestration potential in France.

\section{Acknowledgements}

Soil data gathering was supported by a French Scientific Group of Interest on soils: the GIS Sol, involving the French Ministry of Ecology, the French Ministry of Agriculture, the French Environment and Energy Management Agency (ADEME), the French Institute for Research and Development (IRD) and the National Institute for Agronomic Research (INRA). We thank all the people involved in sampling the sites 
and populating the database. Songchao Chen has received the support of China Scholarship Council for 3 years' Ph.D. study in INRA and Agrocampus Ouest (under grant agreement no. 201606320211).

\section{References}

Accoe, F., Boeckx, P., Busschaert, J., Hofman, G., Van Cleemput, O., 2004. Gross N transformation rates and net $\mathrm{N}$ mineralisation rates related to the $\mathrm{C}$ and $\mathrm{N}$ contents of soil organic matter fractions in grassland soils of different age. Soil Biol. Biochem. 36, 2075-2087.

Angers, D.A., Arrouays, D., Saby N.P.A., Walter, C., 2011. Estimating and mapping the carbon saturation deficit in French agricultural topsoils. Soil Use Manage. 27, 448-452.

Baldock, J., Skjemstad, J., 2000. Role of the soil matrix and minerals in protecting natural organic materials against biological attack. Org. Geochem. 31, 697-710.

Balesdent, J., 1996. The significance of organic separates to carbon dynamics and its modelling in some cultivated soils. Eur. J. Soil Sci. 47, 485-493.

Balesdent, J., Besnard, E., Arrouays, D., Chenu, C.,1998. The dynamics of carbon in particle-size fractions of soil in a forest-cultivation sequence. Plant Soil. 201, 49-57.

Barré, P., Angers, D.A., Basile-Doelsch, I., Bispo, A., Cécillon, L., Chenu, C., Chevallier, T., Derrien, D., Eglin, T.K., and Pellerin, S. 2017. Ideas and perspectives: Can we use the soil carbon saturation deficit to quantitatively assess the soil carbon storage potential, or should we explore other 
strategies?, Biogeosciences Discuss., https://doi.org/10.5194/bg-2017-395, 2017.

308

309

Batjes, N.H., 1996. Total carbon and nitrogen in soils of the world. Eur. J. Soil Sci. 47, 151-163.

Bellamy, P.H., Loveland, P.J., Bradley, R.I., Lark, R.M., Kirk, G.J., 2005. Carbon losses from all soils across England and Wales 1978-2003. Nature. 437, 245248.

Bradford, M.A., Wieder, W.R., Bonan, G.B., Fierer, N., Raymond, P.A., Crowther, T.W., 2016. Managing uncertainty in soil carbon feedbacks to climate change. Nat. Clim. Change. 6, 751-758.

Brus, D.J., de Gruijter, J.J., 1997. Random sampling or geostatistical modelling? Choosing between design-based and model-based sampling strategies for soil (with discussion). Geoderma. 80, 1-44.

Cambardella, C.A., Elliott, E.T., 1992. Particulate soil organic-matter changes across a grassland cultivation sequence. Soil Sci. Soc. Am. J. 56, 777-783.

Canadell, J.G., Le Quéré, C., Raupach, M.R., Field, C.B., Buitenhuis, E.T., Ciais, P., Conway, T.J., Gillett, N.P., Houghton, R.A., Marland, G., 2007. Contributions to accelerating atmospheric $\mathrm{CO}_{2}$ growth from economic activity, carbon intensity, and efficiency of natural sinks. P. Natl. Acad. Sci. USA. 104, 18866-18870.

Carter, M.R., Gregorich, E.G., Angers, D.A., Donald, R.G., Bolinder, M.A., 1998. Organic $\mathrm{C}$ and $\mathrm{N}$ storage, and organic $\mathrm{C}$ fractions, in adjacent cultivated and forested soils of eastern Canada. Soil Till. Res. 47, 253-261. 
Chabbi, A., Lehmann, J., Ciais, P., Loescher, H.W., Cotrufo, M.F., Don, A., SanClements, M., Schipper, L., Six, J., Smith, P., Rumpel, C., 2017. Aligning agriculture and climate policy. Nat. Clim. Change. 7, 307-309.

Chen, S., Martin, M.P., Saby, N.P.A., Walter, C., Angers, D.A., Arrouays, D., 2018. Fine resolution map of top-and subsoil carbon sequestration potential in France. Sci. Total Environ. 630, 389-400.

Chenu, C., Angers, D.A., Barré, P., Derrien, D., Arrouays, D., Balesdent, J., 2018. Increasing organic stocks in agricultural soils: Knowledge gaps and potential innovations. Soil Till. Res. https://doi.org/10.1016/j.still.2018.04.011.

Chenu, C., Balabane, M., Pétraud, J.P., Arrouays, D., Champdavoine, V., 2004. Compartimentation et fractionnement du carbone organique des sols. Test de mise en « routine » de la détermination des matières organiques particulaires sur le RMQS. (In French)

Conant, R.T., Paustian, K., Elliott, E.T., 2001. Grassland management and conversion into grassland: Effects on soil carbon. Ecol. Appl. 11, 343-355.

Conant, R.T., Six, J., Paustian, K., 2003. Land use effects on soil carbon fractions in the southeastern United States. I. Management-intensive versus extensive grazing. Biol. Fert. Soils. 38, 386-392.

Coppin, F., Chabroullet, C., Martin-Garin, A., 2009. Selenite interactions with some particulate organic and mineral fractions isolated from a natural grassland soil. Eur. J. Soil Sci. 60, 369-376. 
Dignac, M.F., Derrien, D., Barré, P., Barot, S., Cécillon, L., Chenu, C., Chevallier, T., Freschet, G.T., Garnier, P., Guenet, B., Hedde, M., 2017. Increasing soil carbon storage: mechanisms, effects of agricultural practices and proxies. A review. Agron. Sustain. Dev. 37, 14.

Eurostat, 2015. Early estimates of $\mathrm{CO}_{2}$ emissions from energy use in $2014, \mathrm{CO}_{2}$ emissions in the EU estimated to have decreased by 5\% compared with 2013.

Guo, L.B., Gifford, R., 2002. Soil carbon stocks and land use change: A meta analysis. Glob. Change Biol. 8, 345-360.

Hassink, J., 1997. The capacity of soils to preserve organic $c$ and $n$ by their association with clay and silt particles. Plant Soil. 191, 77-87.

John, B., Yamashita, T., Ludwig, B., Flessa, H., 2005. Storage of organic carbon in aggregate and density fractions of silty soils under different types of land use. Geoderma. 128, 63-79.

Jolivet, C., Arrouays, D., Leveque, J., Andreux, F., Chenu, C., 2003. Organic carbon dynamics in soil particle-size separates of sandy Spodosols when forest is cleared for maize cropping. Eur. J. Soil Sci. 54, 257-268.

Lal, R., 2004. Soil carbon sequestration impacts on global climate change and food security. Science. 304, 1623-1627.

Lal, R., 2010. Managing soils and ecosystems for mitigating anthropogenic carbon emissions and advancing global food security. BioScience. 60, 708-721. 
Le Quéré, C., Andrew, R.M., Canadell, J.G., Sitch, S., Korsbakken, J.I., Peters, G.P., Manning, A.C., Boden, T.A., Tans, P.P., Houghton, R.A., Keeling, R.F., Alin, S., Andrews, O.D., Anthoni, P., Barbero, L., Bopp, L., Chevallier, F., Chini, L.P., Ciais, P., Currie, K., Delire, C., Doney, S.C., Friedlingstein, P., Gkritzalis, T., Harris, I., Hauck, J., Haverd, V., Hoppema, M., Klein Goldewijk, K., Jain, A.K., Kato, E., Körtzinger, A., Landschützer, P., Lefèvre, N., Lenton, A., Lienert, S., Lombardozzi, D., Melton, J.R., Metzl, N., Millero, F., Monteiro, P.M.S., Munro, D.R., Nabel, J.E.M.S., Nakaoka, S.I., O'Brien, K., Olsen, A., Omar, A.M., Ono, T., Pierrot, D., Poulter, B., Rödenbeck, C., Salisbury, J., Schuster, U., Schwinger, J., Séférian, R., Skjelvan, I., Stocker, B.D., Sutton, A.J., Takahashi, T., Tian, H., Tilbrook, B., van der Laan-Luijkx, I.T., van der Werf, G.R., Viovy, N., Walker, A.P., Wiltshire, A.J., Zaehle, S., 2016. Global carbon budget 2016. Earth Syst. Sci. Data. 8, 605-649.

Leifeld, J., Fuhrer, J., 2009. Long-term management effects on soil organic matter in two cold, high-elevation grasslands: clues from fractionation and radiocarbon dating. Eur. J. Soil Sci. 60, 230-239.

Lu, M., Zhou, X., Luo, Y., Yang, Y., Fang, C., Chen, J., Li, B., 2011. Minor stimulation of soil carbon storage by nitrogen addition: a meta-analysis. Agr. Ecosyst. Environ. 140, 234-244.

Lugato, E., Bampa, F., Panagos, P., Montanarella, L., Jones, A., 2014. Potential carbon sequestration of European arable soils estimated by modelling a comprehensive set of management practices. Glob. Change Biol. 20, 35573567. 
Martin, M.P., Wattenbach, M., Smith, P., Meersmans, J., Jolivet, C.C., Boulonne, L., Arrouays, D., 2011. Soil organic carbon stocks distribution in France. Biogeosciences. 8, 1053-1065.

McNally, S., Beare, M., Curtin, D., Meenken, E.D., Kelliher, F.M., Calvelo Pereira R., Shen, Q., Baldock, J., 2017. Soil carbon sequestration potential of permanent pasture and continuous cropping soils in New Zealand. Glob. Change Biol. 23, 4544-4555.

Meersmans, J, Martin, M.P, Lacarce E, De Baets, S, Jolivet, C, Boulonne, L, Lehmann, S, Saby, N.P.A, Bispo, A, Arrouays, D., 2012. A high resolution map of the French soil organic carbon. Agron. Sustain. Dev. 32, 841-851.

Minasny, B., Malone, B.P., McBratney, A.B., Angers, D.A., Arrouays, D., Chambers, A., Chaplot, V., Chen, Z.S., Cheng, K., Das, B.S., Field, D.J., Gimona, A, Hedley, C.B., Hong, S.Y., Mandal, B., Marchant, B.P., Martin, M., McConkey, B.G., Mulder, V.L., O'Rourke S., Richer-de-Forges A.C., Odeh, I., Padarian, J., Paustian, K., Pan, G., Poggio, L., Savin, I., Stolbovoy, V., Stockmann, U., Sulaeman, Y., Tsui, C-C., Vågen, T.-G., van Wesemael B., and Winowiecki, L., 2017. Soil carbon 4 per mille. Geoderma. 292, 59-86.

Mulder, V.L., Lacoste, M., Richer-de-Forges, A.C., Martin, M.P., Arrouays, D. 2016. National versus global modelling the 3D distribution of soil organic carbon in mainland France. Geoderma, 263, 16-34.

O'Rourke, S.M., Angers, D.A., Holden, N.M., McBratney, A.B., 2015. Soil organic carbon across scales. Glob. Change Biol. 21, 3561-3574. 
414 Paustian, K., Lehmann, J., Ogle, S., Reay, D., Robertson, G.P., Smith, P., 2016. Climate-smart soils. Nature, 532, 49-57.

416

417

Post, W.M., Kwon, K.C., 2000. Soil carbon sequestration and land-use change: Processes and potential. Glob. Change Biol. 6, 317-327.

Poulton, P., Johnston, J., MacDonald, A., White, R., Powlson, D., 2018 Major limitations to achieving " 4 per 1000 "increases in soil organic carbon stock in temperate regions: evidence from long $\square$ term experiments at Rothamsted Research, UK. Glob. Change Biol. 24, 2563-2584.

Rumpel, C., Eusterhues, K., Kögel-Knabner, I., 2004. Location and chemical composition of stabilized organic carbon in topsoil and subsoil horizons of two acid forest soils. Soil Biol. Biochem. 36, 177-190.

Sanderman, J., Hengl, T., Fiske, G.J., 2017. Soil carbon debt of 12,000 years of human land use. P. Natl. Acad. Sci. USA. 114, 9575-9580.

Six, J., Conant, R., Paul, E.A., Paustian, K., 2002. Stabilization mechanisms of soil organic matter: Implications for c-saturation of soils. Plant Soil. 241, 155-176.

Smith, P., 2005. An overview of the permanence of soil organic carbon stocks: Influence of direct human $\square$ induced, indirect and natural effects. Eur. J. Soil Sci. $56,673-680$.

Smith, P., Davies, C.A., Ogle, S., Zanchi, G., Bellarby, J., Bird, N., Boddey, R.M., McNamara, N.P., Powlson, D., Cowie, A. and Noordwijk, M., 2012. Towards an integrated global framework to assess the impacts of land use and management 
change on soil carbon: current capability and future vision. Glob. Change Biol. $18,2089-2101$.

Smith, P., Martino, D., Cai, Z., Gwary, D., Janzen, H., Kumar, P., McCarl, B., Ogle, S., O’Mara, F., Rice, C., Scholes, B., Sirotenko, O., Howden, M., McAllister, T., Pan, G., Romanenkov, V., Schneider, U., Towprayoon, S., Wattenbach, M., Smith, J., 2008. Greenhouse gas mitigation in agriculture. Philos. T. R. Soc. B. $363,789-813$.

Soussana, J-F., Loiseau, P., Vuichard, N., Ceschia, E., Balesdent, J., Chevallier, T., Arrouays, D., 2004. Carbon cycling and sequestration opportunities in temperate grasslands. Soil Use Manage. 20, 219-230.

Stewart, C.E., Paustian, K., Conant, R.T., Plante, A.F., Six, J., 2007. Soil carbon saturation: Concept, evidence and evaluation. Biogeochemistry. 86, 19-31.

Stockmann, U., Adams, M.A., Crawford, J.W., Field, D.J., Henakaarchchi, N., Jenkins, M., Minasny, B., McBratney, A.B., de Remy de Courcelles, V., Singh, K., Wheeler, I., Abbott, L., Angers, D.A., Baldock, J., Bird, M., Brookes, P.C., Chenu, C., Jastrow, J.D., Zimmermann, M., 2013. The knowns, known unknowns and unknowns of sequestration of soil organic carbon. Agr. Ecosyst. Environ. 164, 80-99.

Stockmann, U., Padarian, J., McBratney, A., Minasny, B., de Brogniez, D., Montanarella, L., Hong, S.Y., Rawlins, B.G., Field, D.J., 2015. Global soil organic carbon assessment. Glob. Food Secur.-Agr. 6, 9-16. 
456 van Groenigen, J.W., van Kessel, C., Hungate,B.A., Oenema, O., Powlson, D.S., Jan van Groenigen, K., 2017. Sequestering soil organic carbon: a nitrogen dilemma. Environ. Sci. Technol. 51, 4738-4739.

459 Wiesmeier, M., Schad, P., von Lützow, M., Poeplau, C., Spörlein, P., Geuß, U., Hangen, E., Reischl, A., Schilling, B., Kögel-Knabner, I., 2014. Quantification of functional soil organic carbon pools for major soil units and land uses in southeast Germany (Bavaria). Agr. Ecosyst. Environ.185, 208-220. 
463 Fig. 1. Relative frequency distribution of SOC $\mathrm{spd}$ for three land uses in topsoil (0-30

$464 \mathrm{~cm})$. The number of samples is indicated for each land use.

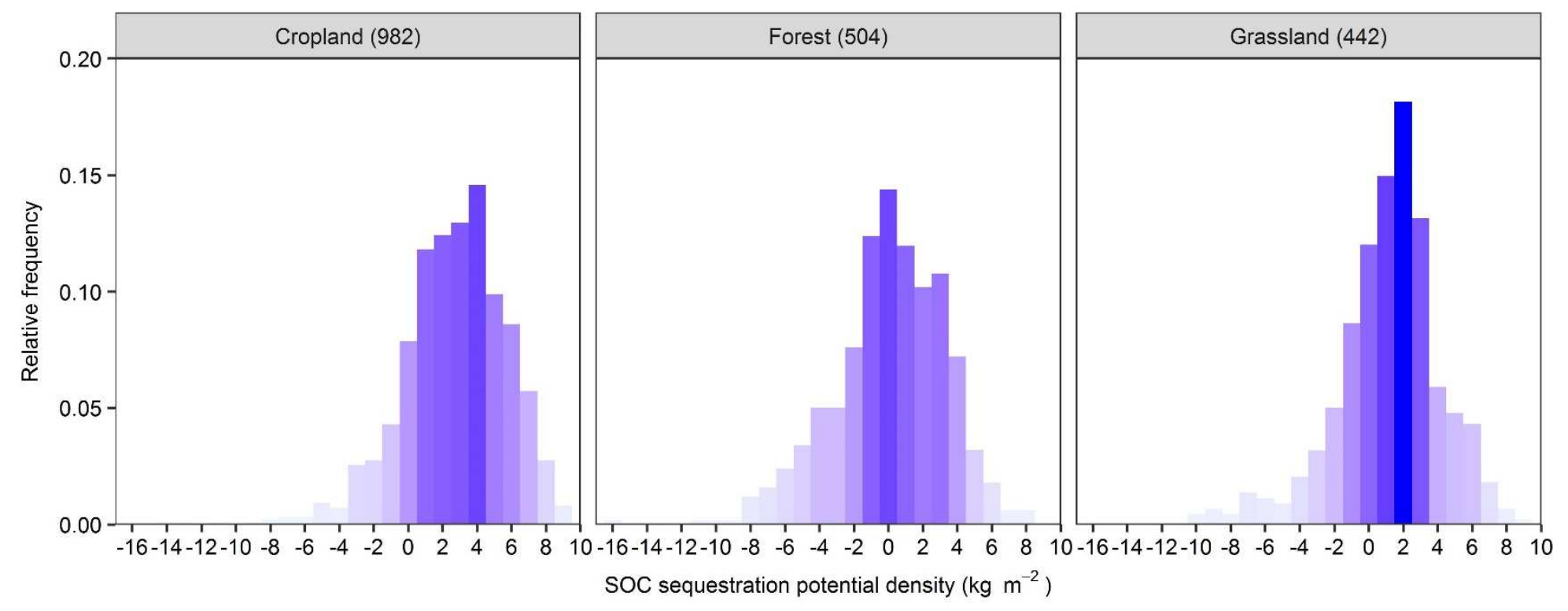


Fig. 2. Correlation between the fine fraction content and $\mathrm{SOC}_{\text {spd. }}$. Solid black lines

466 black dashed line and black dot dashed line dashed black lines are fitted lines for

467 cropland, forest and grassland, respectively.

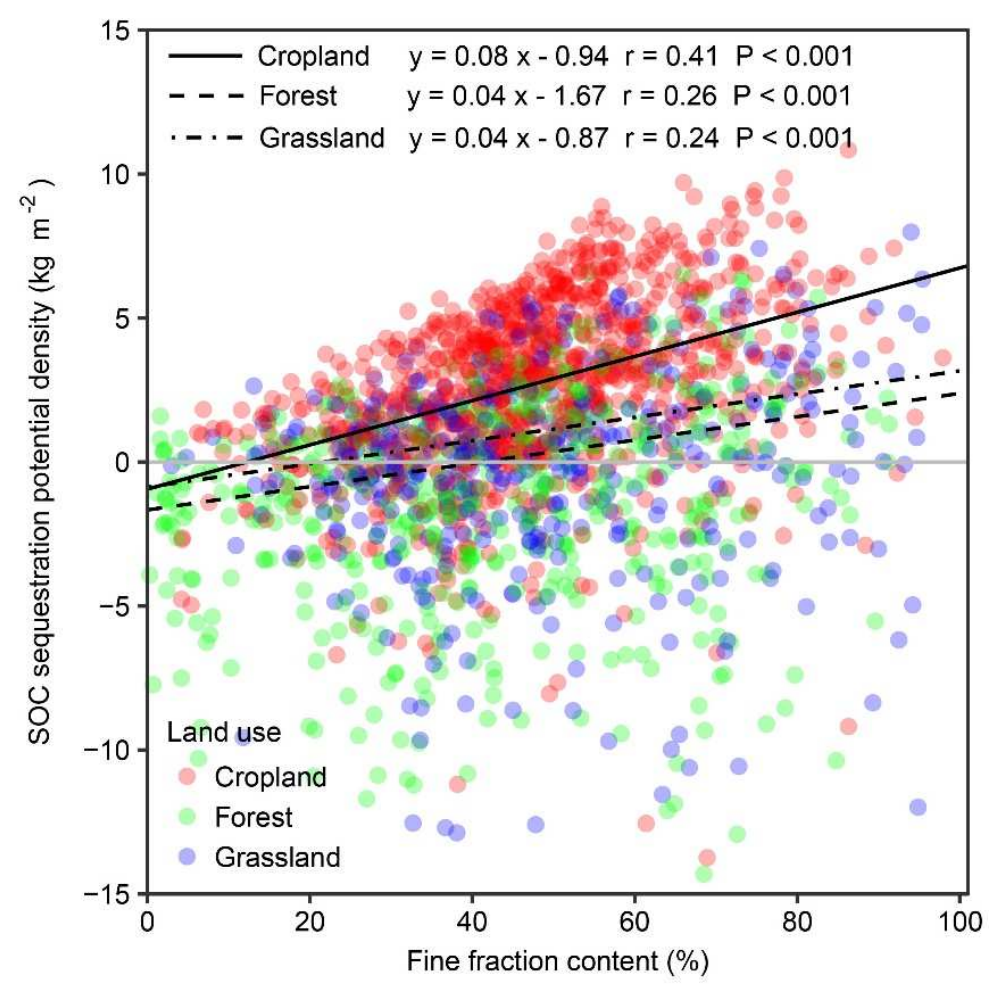


469 Fig. 3. The influence of the proportion of SOC in the fine fraction on the national

470 estimates of $\mathrm{SOC}_{\text {spd }}$ stocks in French topsoil. Solid lines show how SOC $\mathrm{spd}$ stocks

471 change with proportion of $\mathrm{SOC}_{\text {fine }}$ under three land uses and dashed lines are the

472 corresponding minimal and maximal $\mathrm{SOC}_{\text {spd }}$ stocks for each land use.

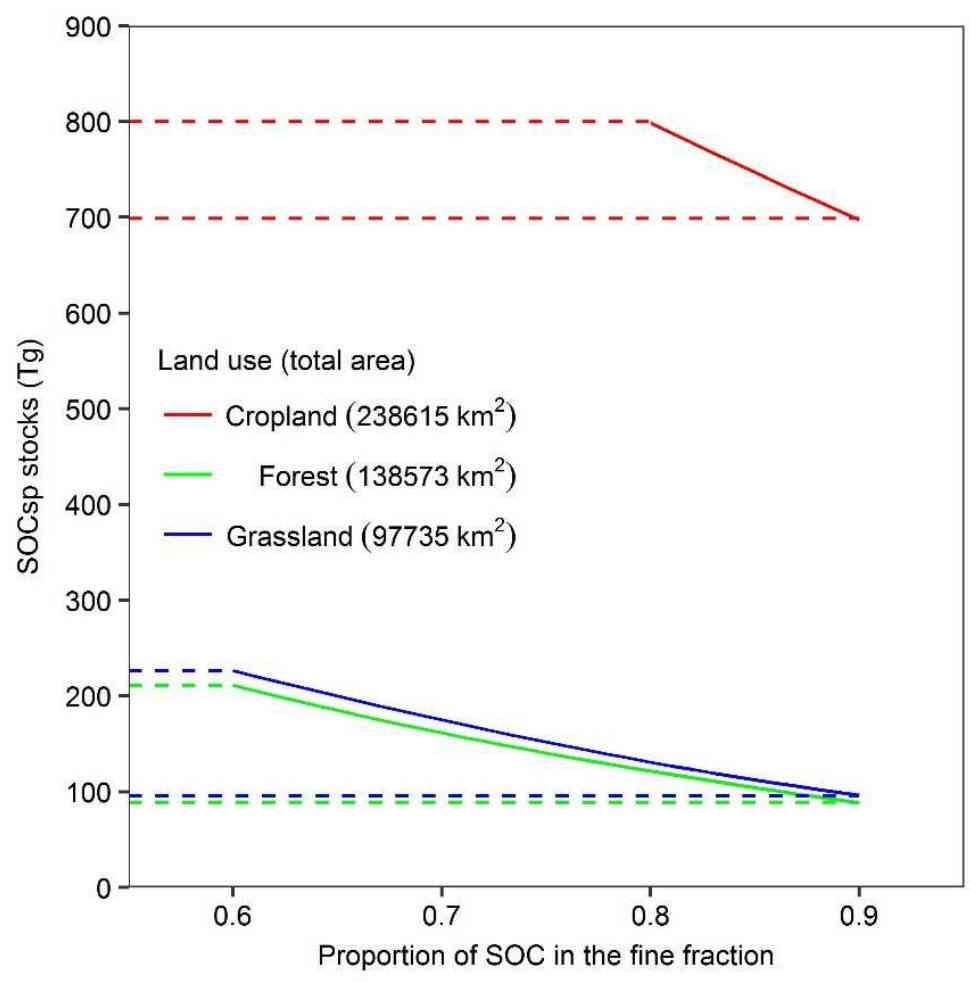


474 Figure 4. Sensitivity analysis: influence of the SOC fine proportion distribution on

$475 \quad$ SOC $_{\text {spd }}$
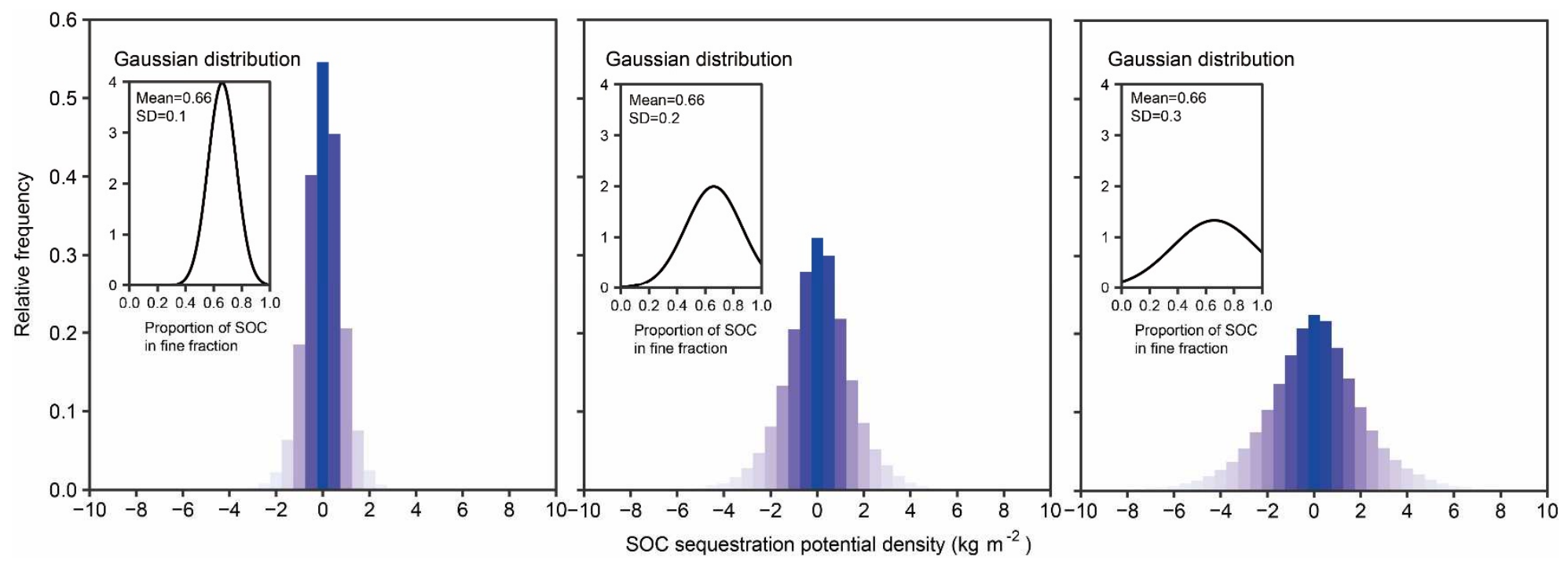

476 
477 Table 1. Proportion of SOC in fine fraction among total SOC for grassland and forest

478 topsoil (after Chen et al., 2018)

\begin{tabular}{|c|c|c|c|c|c|c|c|c|}
\hline Land use & Country & $\begin{array}{l}\text { Sampling } \\
\text { depth (cm) }\end{array}$ & $\begin{array}{l}\text { Number of } \\
\text { sampling sites }\end{array}$ & $0-20 \mu \mathrm{m}^{\mathrm{a}}$ & $0-50 \mu \mathrm{m}^{b}$ & $0-53 \mu \mathrm{m}^{c}$ & $0-63 \mu \mathrm{m}^{d}$ & Reference \\
\hline \multirow{5}{*}{ Grassland } & Canada & $0-15$ & 2 & & & 0.65 & & Carter et al. (1998) \\
\hline & Belgium & $0-20$ & 6 & & 0.58 & & & Accoe et al. (2004) \\
\hline & France & $0-30$ & 2 & & 0.85 & & & Chenu et al. (2004) \\
\hline & UK & $0-18$ & 1 & & 0.69 & & & Coppin et al. (2009) \\
\hline & Germany & $0-20$ & 11 & & & & 0.70 & Wiesmeier et al. (2014) \\
\hline \multirow[t]{2}{*}{ Forest } & Canada & $0-15$ & 1 & & & 0.69 & & Carter et al. (1998) \\
\hline & France & $0-30$ & 1 & 0.66 & 0.67 & & & Balesdent et al. (1998) \\
\hline
\end{tabular}

479 a proportion of SOC in 0-20 $\mu \mathrm{m}$ among total SOC content;

$480 \mathrm{~b}$ proportion of SOC in 0-50 $\mu \mathrm{m}$ among total SOC content;

$481{ }^{c}$ proportion of SOC in 0-53 $\mu \mathrm{m}$ among total SOC content;

$482 \mathrm{~d}$ proportion of SOC in 0-63 $\mu \mathrm{m}$ among total SOC content. 


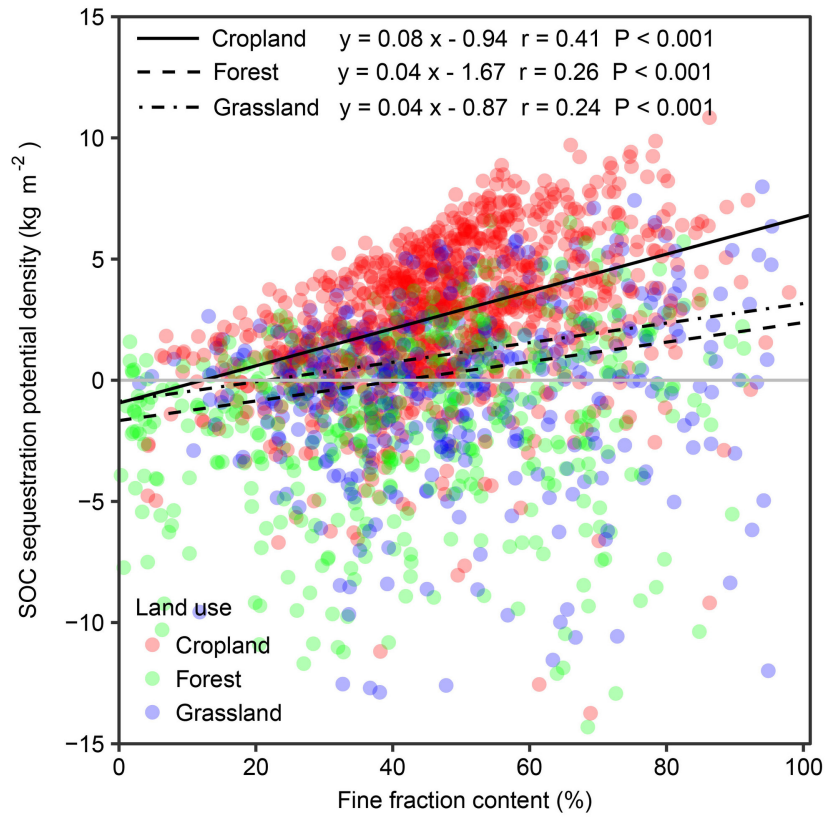




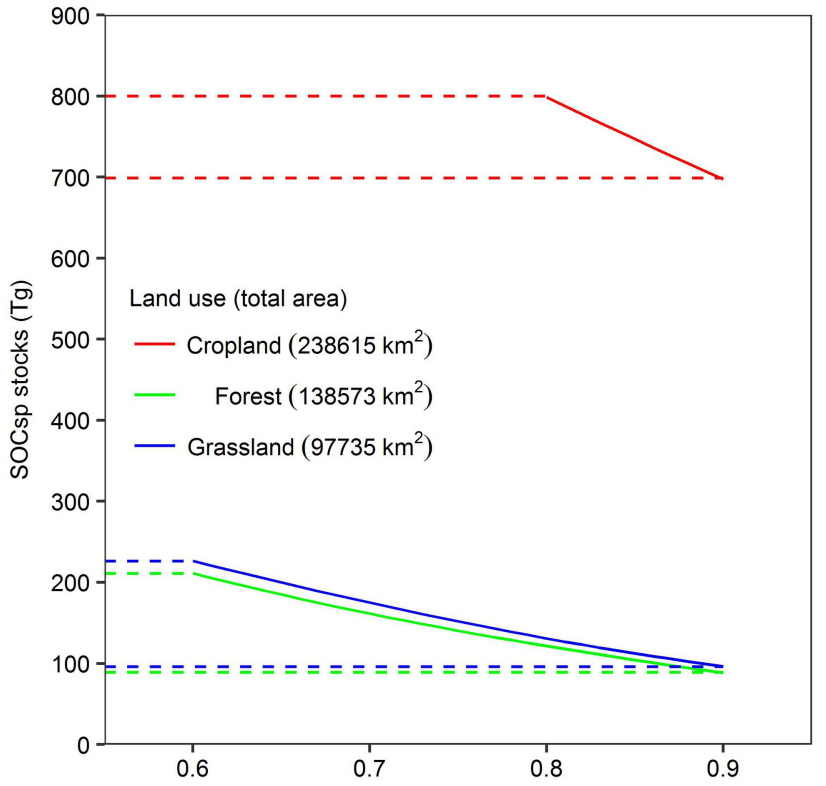

Proportion of SOC in the fine fraction 


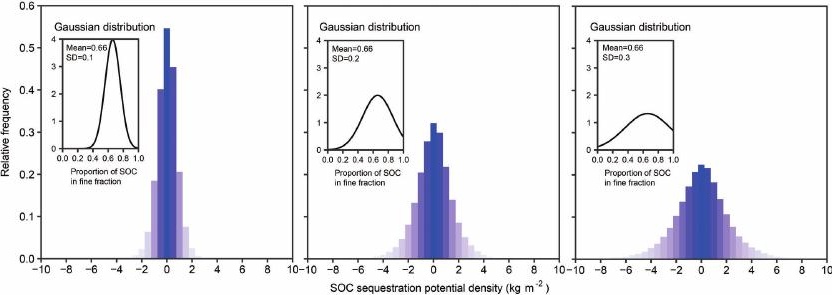

